\title{
ESTÁGIO SUPERVISIONADO NA LICENCIATURA EM LETRAS: UM ESPAÇO-TEMPO DE CONSTRUÇÃO DA IDENTIDADE DOCENTE DO PROFESSOR DE LÍNGUA PORTUGUESA
}

\author{
Gislainy Jennifer da Silva Nascimento ${ }^{1}$, Lívia Suassuna ${ }^{2}$ \\ ${ }^{1}$ Especializanda em Linguística Textual pela Universidade Federal do Rio Grande do Norte - UFRN, Campus Currais \\ Novos, RN. ORCID iD: https://orcid.org/0000-0002-4025-633X. E-mail: gislainyj@gmail.com \\ ${ }^{2}$ Doutora em Linguística pela Universidade Estadual de Campinas - UNICAMP, SP. Atua como professora associada da \\ Universidade Federal de Pernambuco - UFPE, Centro de Educação - Departamento de Métodos e Técnicas de Ensino e \\ Programa de Pós-graduação em Educação. ORCID iD: https://orcid.org/0000-0001-7422-2923. E-mail: \\ livia.suassuna@ufpe.br
}

\section{RESUMO}

Há muito se vêm desenvolvendo pesquisas na área da educação acerca da formação de professores e dos estágios curriculares, como uma das formas de garantir a melhoria dos cursos de licenciatura. Muitos desses estudos buscam compreender como ocorre o processo de identificação do docente em formação com o ofício de ensinar. Nessa perspectiva, este trabalho teve como objetivo analisar a relação entre os estágios supervisionados e o processo de construção da identidade docente do professor de língua portuguesa. Desenvolvemos uma pesquisa qualitativa e documental, na qual analisamos o discurso dos estagiários manifestado em seus relatórios escritos de vivências no campo do estágio. O corpus foi composto pelos trabalhos de 25 graduandos, concluintes do Estágio Curricular Supervisionado em Português 4, do curso de licenciatura em Letras-Português da Universidade Federal de Pernambuco, componente que consiste na regência de turma de ensino médio. Realizamos a análise dos dados com base em categorias teóricas atinentes à identidade e profissionalização docente (CORACINI, 2000; NAGAKOME, 2012; AGUIAR, 2016), à formação docente (SILVESTRE; PLACCO, 2011) e ao estágio (COSTA; LIMA, 2012; PIMENTA; LIMA, 2006). Constatamos que os estagiários reconhecem o estágio como importante etapa formativa do curso, espaço de reflexão acerca da prática pedagógica e processo de construção e reafirmação da identidade e da profissionalidade docente. Ademais, foram identificados diferentes sentimentos e impactos - tanto positivos quanto negativos - causados pela vivência do exercício profissional dos formandos, que também apontaram o que ainda pode ser feito para garantir uma formação mais consistente.

Palavras-chave: Formação de professores. Estágio supervisionado. Identidade docente. Profissionalização docente. Licenciatura em Letras-Português

\section{CURRICULAR INTERNSHIP IN LANGUAGE UNDERGRADUATE: A SPACE-TIME OF CONSTRUCTION OF THE TEACHING IDENTITY OF THE PORTUGUESE LANGUAGE TEACHER}

\begin{abstract}
Recent researches about teacher training and curricular internship have been developed in order to ensure the improvement of the undergraduate courses. Many of these studies seek to understand how the teacher's identifying process in the teaching profession occurs. From this perspective, this work aims to analyze the relation between supervised internship and the process of building Portuguese language teachers' identity. We developed a qualitative and documentary research in which we analyzed the discourse of the interns expressed in their written reports of experiences during the internship. The data analysis consisted of the works of 25 undergraduates, who completed the supervised internship in Portuguese 4 of the undergraduate degree course in Portuguese Language at the Federal University of Pernambuco, a component that consists of conducting a High School class. We performed the analysis based on theoretical categories related to the identity and teaching professionalization (CORACINI, 2000; NAGAKOME, 2012; AGUIAR, 2016; PERES e GRECO, 2014), teacher training (SILVESTRE; PLACCO, 2011) and
\end{abstract}


supervised internship (COSTA; LIMA, 2012; PIMENTA; LIMA, 2006). We concluded that the interns recognize the internship as an important formative stage of the course, a space for reflection about the pedagogical practice and the process of construction and reaffirmation of the identity and teaching professionality. Furthermore, the interns identified different feelings and impacts - both positives and negatives - as a result of their professional experience and also pointed out what can still be done to ensure a more consistent formation.

Keywords: Teacher training; supervised internship; teacher identity; teacher professionalization; undergraduate in Portuguese Language

\section{PRÁCTICA SUPERVISADA EN LICENCIATURA EN LETRAS: UN ESPACIO-TIEMPO DE CONSTRUCCIÓN DE LA IDENTIDAD DOCENTE DEL PROFESOR DE LENGUA PORTUGUESA}

\section{RESUMEN}

Desde hace mucho tiempo se han desarrollado investigaciones en el área de la educación acerca de formación de profesores y prácticas curriculares, como una de las formas de garantizar la mejora de los cursos de licenciatura. Muchos de estos estudios buscan comprender cómo se da el proceso de identificación del docente en formación con la labor de enseñanza. En esta perspectiva, este trabajo tuvo como objetivo analizar la relación entre las prácticas supervisadas y el proceso de construcción de la identidad docente del profesor de portugués. Desarrollamos una investigación cualitativa y documental, en la que analizamos el discurso de los pasantes expresado en sus relatos escritos de experiencias en el ámbito de la pasantía. El corpus estuvo compuesto por los trabajos de 25 estudiantes de pregrado, quienes completaron la Práctica Curricular Supervisada en Portugués 4, de la carrera de Licenciatura en LetrasPortugués de la Universidad Federal de Pernambuco, que consiste en una pasantía para impartir clases en un grupo de bachillerato. Realizamos un análisis de datos basado en categorías teóricas relacionadas con la identidad y profesionalización docente (CORACINI, 2000; NAGAKOME, 2012; AGUIAR, 2016), con la formación docente (SILVESTRE; PLACCO, 2011) y con la práctica supervisada (COSTA; LIMA, 2012; PIMENTA; LIMA, 2006). Encontramos que los pasantes reconocen la pasantía como una importante etapa formativa del curso, un espacio de reflexión sobre la práctica pedagógica y el proceso de construcción y reafirmación de la identidad y de la profesionalidad docente. Además, se identificaron diferentes sentimientos e impactos, tanto positivos como negativos, provocados por la experiencia de la práctica profesional de los pasantes, que también señaló lo que aún se puede hacer para asegurar una formación más consistente.

Palabras-clave: Formación de profesores; prácticas supervisadas; identidad docente; profesionalización docente; licenciatura en Letras-Portugués.

\section{INTRODUÇÃO}

A formação inicial de graduação consiste numa importante etapa da construção identitária do profissional, sobretudo da docência. E, dentro dela, adquire especial relevância o estágio curricular, porque, como aponta Lima (2008, p. 201), ao constituir a formação de professores a partir das práticas de ensino, o estágio é, por excelência, um "espaço de mediação reflexiva entre a universidade, a escola e a sociedade". E, por essa característica conciliadora, torna-se um singular espaço-tempo de construção identitária do profissional da educação.

A esse respeito, lza et al. (2014) realizaram um estudo sobre a identidade docente e as muitas faces do "ser professor" e nele afirmam que, uma vez que a identidade em geral é uma construção social e cultural, a identidade profissional corresponderia à significação e à importância atribuídas, por sujeitos historicamente situados, a um ofício. E, em se tratando da docência, em específico, há uma considerável relevância social atribuída ao exercício do magistério, que tem seu início nos cursos de graduação, com a contribuição substancial dos estágios supervisionados. Além disso, lza et al. (2014) consideram que a construção da identidade profissional docente faria parte de um longo processo que deveria envolver, também, a compreensão e a consciência do próprio professor em formação quanto ao seu exercício profissional, "pois é preciso tempo para assimilar a formação, para aprender como agir, para tomar decisões e 
principalmente para se reconhecer como um formador das futuras gerações." (IZA et al., 2014, p. 276).

Ainda buscando ratificar a visão dos estágios como espaço e tempo de desenvolvimento da identidade do profissional docente, pode-se citar aqui a pesquisa, de cunho qualitativo e etnográfico, realizada por Castro e Salva (2012), a qual foi empreendida com base nas experiências de estágio curricular supervisionado de sete estudantes de Pedagogia em uma universidade do estado do Rio Grande do Sul. As autoras objetivaram entender o processo de aprendizagem da profissão docente a partir do olhar dos estagiários em suas atividades de estágio. Em termos do objetivo específico, o estudo procurou identificar quais saberes os acadêmicos julgam necessários a quem ensina e como eles se percebem em relação a esses saberes, antes e depois dos estágios. Em termos metodológicos, foram realizadas entrevistas com os estudantes do curso mencionado e as respostas fornecidas pelos sujeitos foram analisadas em consonância com os pressupostos teóricos adotados pelas autoras.

De maneira ampla, ficou evidenciado que os graduandos enxergavam o estágio a partir de três enfoques: "1ㅇ) espaço para obtenção de experiência prática da docência; 2 ㅇ) possibilidade de conhecer e interagir com a realidade escolar; 3) momento para colocar em prática as aprendizagens do curso, a fim de verificar se a formação atende às necessidades impostas à futura profissão." (CASTRO; SALVA, 2012, p. 4). Ademais, os estagiários afirmaram reconhecer o estágio não como uma atividade meramente instrumental, mas sim como espaço que possibilita a reflexão sobre as ações pedagógicas ali desenvolvidas.

Outro ponto destacado pelos acadêmicos de Pedagogia com relação às aprendizagens do estágio curricular foi a oportunidade de "ver-se como professor", uma vez que as práticas vivenciadas contribuíram para a constituição de sua identidade docente, a qual, como proposto pelas autoras, corresponde um processo de construção e reconstrução constante ao longo da formação e da carreira profissional dos professores. As autoras lembram que não só o estágio é um espaço privilegiado para as aprendizagens sobre a docência por parte dos licenciandos, mas que "[...] as práticas, as concepções e os objetivos por ele almejados são também participantes da construção de sua identidade." (CASTRO; SALVA, 2012, p. 5).

Foi ainda constatada pelos estagiários da pesquisa a existência de três momentos significativos de aprendizagem da prática pedagógica. O primeiro seria "o planejamento da ação": seis entrevistados apontaram que o ato de planejar as aulas é um dos principais saberes construídos no estágio, uma vez que é bastante desafiador adequar o trabalho docente às singularidades do espaço escolar e do alunado. 0 segundo seria "o desenvolvimento da aula": este é um momento para se refletir acerca de questões relativas a autoridade, respeito e afetividade, elementos essenciais para o exercício da profissão docente, como afirmaram três dos entrevistados. $\mathrm{E}$ o terceiro momento de aprendizagem destacado seria "a reflexão sobre o vivido": com relação a esse aspecto, os estagiários reforçaram a importância de a prática docente não ser meramente instrumental ou técnica, mas sim reflexiva e crítica, levando em consideração as especificidades presentes em cada contexto de ensino.

Finalmente, foi possível concluir com o estudo que "essas experiências [...] podem ter contribuído para que os próprios sujeitos reconhecessem a importância de suas ações, enquanto professores, para o crescimento e aprendizagem do outro." (CASTRO; SALVA, 2012, p. 14). ${ }^{1}$

Com base nas discussões até aqui apresentadas, originou-se o presente estudo, que corresponde a um recorte de um trabalho de conclusão do curso de licenciatura em LetrasPortuguês da Universidade Federal de Pernambuco. De modo mais amplo, o trabalho objetivou ampliar a discussão sobre a correlação entre os estágios curriculares e a identidade docente, buscando compreender mais profundamente o processo formativo de futuros professores de português. Dada a configuração do estágio no interior da matriz curricular vigente do referido curso, tivemos interesse de analisar de que maneira e em que aspectos essa correlação poderia estar se manifestando nos relatórios de estágio apresentados pelos licenciandos ao final dos períodos letivos correspondentes. Isso porque, como propõem Iza et al. (2014, p. 290), justifica-se a necessidade de

\footnotetext{
${ }^{1}$ A respeito dos contributos do estágio curricular supervisionado para a construção da identidade profissional docente, recomendamos, além dos estudos aqui descritos, a leitura dos artigos de Quadros e Kochhann (2018) e Pereira e Ovigli (2017).
} 
mais estudos e pesquisas nessa área, uma vez que há uma "[...] dificuldade em se investigar a problemática multifacetada da identidade docente. Mesmo com a contextualização conjunta das pesquisas em andamento, nota-se que os vários aspectos abordados ainda carecem de aprofundamento teórico e metodológico".

Nesse cenário, colocamo-nos o seguinte questionamento: qual a importância dos estágios supervisionados para a formação da identidade do futuro professor de língua portuguesa? Tendo isso em vista, delineamos o seguinte objetivo geral para a nossa pesquisa: investigar as contribuições que os estágios curriculares supervisionados podem trazer para a construção da identidade do professor de língua portuguesa. Já o nosso objetivo específico foi analisar os indícios de construção da identidade docente nos discursos dos professores em formação apresentados em seus relatórios de estágio.

\section{A QUESTÃO DA IDENTIDADE}

Historicamente, diferentes autores, a partir de diferentes perspectivas, propuseram-se a estudar a temática da identidade. Segundo Coracini (2000), o conceito de identidade surge com a noção de um sujeito consciente. Sujeito este que possui, como propõe a autora, um conjunto estável de atributos ou marcas individuais que o diferenciam de outros indivíduos e que contribuem, assim, para a constituição de sua identidade. Ademais, Coracini (2000), ao fazer uma releitura dos estudos de Lacan acerca da infância e do inconsciente freudianos, lembra que o indivíduo não se enxerga como tendo determinadas características por um inatismo que o leva a se reconhecer, mas sim como resultado do "olhar" do outro sobre si: "A formação do eu no 'olhar' do outro inicia a relação da criança com os sistemas simbólicos fora dela mesma, sistemas esses que são internalizados de modo a constituí-la." (CORACINI, 2000, p. 150). Desse modo, a identidade não pode ser vista como algo acabado, uma vez que se trata de um processo em andamento, no qual "só é possível capturar momentos de identificação do sujeito com outros sujeitos, fatos e objetos." (CORACINI, 2000, p. 150).

Nakagome (2012), ao estudar a identidade humana, também afirma que ela não é um produto acabado, antes, corresponde a um processo pelo qual o sujeito se reconhece, se configura e se reconfigura ao longo da vida, à medida que vai se identificando com pessoas, culturas e espaços. A autora comenta: "Diferentemente do que ocorria nas sociedades tradicionais, a identidade é atualmente mais marcada por um esforço de compreensão e construção. Isso permite pensar a identidade como um conceito plural, pois não deixará de ser modificado ao longo de toda a vida." (NAKAGOME, 2012, p. 207). Nakagome (2012, p. 207) afirma, ainda, que, "diante dessa concepção processual da identidade, [...] uma pessoa não é um professor, mas gradualmente se torna um". Tal fato se dá devido ao processo pelo qual um docente se constitui, que vai desde a consciência do querer "tornar-se professor", ou seja, desde a escolha por essa carreira, e se prolonga pela vida profissional.

O processo de identificação dos sujeitos proposto por Coracini (2000) pode ser considerado como referencial para discutirmos a identidade do docente de língua materna. Segundo a autora, a "identificação" do sujeito professor enquanto profissional pode se dar pelo olhar que este tem de si e também pelo olhar do outro sobre ele. Diz a autora: "a partir de nosso exterior, pelas formas através das quais nós imaginamos ser vistos por outros: sei quem sou em relação com o outro que eu não posso ser." (CORACINI, 2000, p. 150).

Além disso, conforme Aguiar (2016), podemos pensar que a identidade do professor é um fenômeno em constante transformação, dentro de um processo de construir e ressignificar os saberes da formação docente, bem como de suas representações individuais enquanto sujeito de sua própria história, acrescidas das representações e significações atribuídas a esse sujeito por diversas instituições sociais, como a própria escola. Tratase, portanto, de um processo complexo que envolve várias experiências do sujeito professor, desde as pessoais às profissionais. Como o autor aponta, em seu estudo acerca das contribuições dos estágios para a construção identitária do licenciando em Letras, "não se pode tratar de questões concernentes à identidade profissional ignorando a relação que ela estabelece com a identidade pessoal de um indivíduo; ambas estão intrinsecamente relacionadas, inseridas num ciclo de causa e efeito em que uma atua sobre a outra." (AGUIAR, 2016, p. 21).

É importante salientarmos ainda que, conforme essa concepção de identidade, o indivíduo passa, ao longo de sua vida, pela 
ressignificação de várias práticas. E, nesse processo de ressignificação e de construção da identidade, o sujeito é capaz de se reconhecer em um ofício, fazendo parte de um processo profissionalizante, identificando-se com as práticas da profissão e se reconhecendo como um certo profissional. Isso porque "o processo de construção de identidades profissionais se faz essencialmente dinâmico em virtude da alteração de ressignificações sociais, cuja revisão provoca alterações nas representações já estabelecidas." (AGUIAR, 2016, p. 23).

Peres e Greco (2014) realizaram uma pesquisa sobre o tema da identidade docente em diferentes escolas estaduais do município de Maringá (PR). O corpus da investigação foram respostas a um questionário fornecidas por professores de língua portuguesa dos anos finais do ensino fundamental e do ensino médio. Por meio da análise dos discursos que emergiram dos questionários, foi possível identificar a imagem do sujeito professor de língua portuguesa construída pelos docentes investigados, bem como analisar o processo de constituição da identidade docente desses sujeitos em correlação com os discursos da mídia.

Primeiramente, as autoras asseveram que "é por meio da linguagem que o indivíduo se coloca como sujeito, e é ainda pela linguagem que a comunicação se estabelece e os indivíduos exercem seus papéis sociais, como 0 de professor, médico, aluno." (PERES; GRECO, 2014, p. 192). Pensando nisso, e relembrando que a noção de identidade é construída na interação do "eu" com o "outro" em determinados tempos e espaços, devemos concordar em que o discurso é uma prática construtora de identificações sociais, uma vez que ele é sempre realizado sujeitos situados.

Posto isso, as autoras afirmam que o discurso midiático construído acerca da identidade docente em grande parte representa o professor de maneira negativa, desvalorizandoo. Tal fato pôde ser constatado a partir de uma pesquisa anterior realizada por Greco (2012), citada por Peres e Greco (2014), na qual a autora, buscando analisar a imagem do professor construída pela revista semanal Veja, constatou que "o professor é visto como o responsável pela má qualidade de ensino, pela violência na escola e pelo fato de os alunos não se interessarem pelos estudos. Além do mais, o professor não está preocupado com o aprendizado dos alunos e não faz planejamento, limitando-se ao livro didático." (PERES; GRECO, 2014, p. 196).

As autoras salientam ainda que os discursos analisados vieram de pessoas não ligadas ao ensino e que não têm conhecimento sobre a realidade escolar e da sala de aula. Acrescenta-se a isso o fato de a mídia ter papel de destaque nas práticas discursivas de nossa sociedade, produzindo e reproduzindo opiniões e visões dos sujeitos. O resultado disso é o apagamento, o silenciamento e a denegação da voz do professor, o qual perde "a oportunidade de assumir seu discurso, constituir-se como sujeito e criar sua própria imagem discursiva." (PERES; GRECO, 2014, p. 196).

Tendo em conta esses princípios, Peres e Greco questionaram docentes formados e atuantes sobre as suas escolhas e motivações profissionais. Constataram que, para eles, o professor é um ser social, inserido num contexto de desvalorização profissional e de apagamento de suas práticas. No que tange à motivação para a escolha dessa carreira profissional, as autoras constataram, a partir das falas dos entrevistados, que essa escolha que se deu por falta de opção ou por apreço pela língua portuguesa e pela literatura, mas não porque ser professor, lecionar, ensinar era o que os motivava. Outros escolheram a profissão como segunda opção por não terem sido aprovados no curso que almejavam. E apenas um sujeito disse que escolheu a profissão por ter tido um professor modelo, o que o aproxima da lógica do "professor amigo, herói, missionário" comentada por Coracini (2000). Com base nos resultados obtidos e com exceção dos professores entrevistados que escolheram a profissão inspirados nos "professores modelos" que eles tiveram, "podemos observar que os sujeitos não desejavam ser professor de Língua Portuguesa, mas, como não podiam cursar a profissão pretendida, fizeram o curso porque tiravam notas razoáveis em Português ou porque gostavam de Literatura." (PERES; GRECO, 2014, p. 200).

Os resultados das pesquisas detalhadas acima revelam uma imagem do professor, em certa medida, ampla. Sendo assim, entendemos que a identidade docente que vem sendo constituída em nossa sociedade é pautada na dualidade valorização $x$ desvalorização, $e$ também reflete as diferentes formas como as práticas sociais e os ofícios profissionais são vistos e valorados. 


\section{A QUESTÃO DA FORMAÇÃO}

A formação de professores corresponde a um processo complexo e vasto, que envolve uma gama de saberes múltiplos e complementares, entre os quais estão os saberes docentes, como afirmado por Aguiar (2016). Dessa maneira, ao procurar compreender a formação docente, deve-se ter em mente que esse processo não tem fim nos cursos de graduação, mas se estende por toda a trajetória profissional, ressignificando-se à medida que os saberes da profissão vão se tecendo com os saberes individuais do sujeito professor.

Silvestre e Placco (2011), em trabalho sobre modelos de formação e estágios curriculares, reconhecem o quanto o processo de formação de professores sofreu mudanças ao longo da história e, contemporaneamente, pode ser considerado um campo que avançou muito em termos de profissionalização. Para elas, é necessário sempre questionar-se "para que" se está formando professores. E, dentre outras justificativas, elas consideram que se forma alguém, no campo educacional, antes de tudo, visando à sua humanização.

Outro elemento que se faz essencial na discussão acerca da formação docente, conforme Silvestre e Placco (2011), são os estágios curriculares, enquanto espaço e tempo do contato inicial dos futuros docentes com a realidade da profissão e o contexto escolar. A relação dos estágios com esse componente humanizador da formação, conforme apontam as autoras, se dá pelo fato de que essa etapa do curso de formação inicial permite desenvolver "instrumentos intelectuais" que facilitem 0 processo de autorreflexão da prática docente, e também funciona como oportunidade de refletir criticamente sobre a educação e a realidade social mais ampla. Os estágios funcionam, portanto, como base para a construção de saberes especializados por parte do futuro professor, além de permitirem a vivência de experiências concretas que podem contribuir para a construção da sua identidade enquanto profissional.

Reconhecida a importância do estágio curricular como etapa crucial para a formação docente, devemos entender os três paradigmas historicamente instaurados na educação como adequados para se adotar nos cursos de formação e que, ao longo do tempo, foram recontextualizados até chegarmos à proposição atual, que se aproxima mais da concepção de formação humanizadora como prática social.

O primeiro modelo é o paradigma da formação de racionalidade técnica, dominante em boa parte da história da educação brasileira. Nesse modelo, entende-se a prática docente como "um conjunto de aplicações teóricas e técnicas, disponível a priori e pautado nos procedimentos racionais da ciência, visando à resolução instrumental dos problemas apresentados na situação de ensino" (SILVESTRE; PLACCO, 2011, p. 34). Ou seja, tem-se a teoria determinando e predominando sobre o que deve ocorrer na prática. Assim, estabelece-se uma supremacia do conhecimento teórico e técnico sobre o prático e, consequentemente, um distanciamento entre os sujeitos do "fazer" e os elaboradores do "saber". Isso porque se acreditava que "um sólido suporte teórico oferecido ao aluno, no início do curso, dar-lhe-ia condições para a atuação prática em qualquer realidade." (SILVESTRE; PLACCO, 2011, p. 34).

Somando-se aos pressupostos do paradigma de racionalidade técnica, há o pensamento de que os desafios que envolvem as situações decorrentes do contexto de sala de aula são vistos como "problemas" a serem "resolvidos" com a instrumentalização de técnicas. Precisamos lembrar que essa é uma visão equivocada, conforme aponta Contreras (2002), citado por Silvestre e Placco (2011), não só porque considera que os contextos de ensino e aprendizagem são homogêneos e, portanto, devem ser desenvolvidos com atividades e propostas de ensino uniformes, mas também porque concebe a formação como espaço para "solucionar problemas", o que prepara o docente do ponto de vista técnico, mas ignora a necessidade de formar um professor que, imbuído da função social de sua profissão, irá atuar para formar sujeitos críticos e emancipados.

Esse, portanto, seria um modelo de formação também limitado, uma vez que vai de encontro à proposta humanizadora e emancipatória de ensino, que considera as práticas de sala de aula, antes de tudo, como práticas sociais. Por isso, como forma de superar o modelo de formação de racionalidade técnica, Silvestre e Placco (2011) apontam a emergência do modelo da racionalidade prática, uma vez que é necessário recuperar as "competências legítimas e necessárias da prática de ensino que ficaram subordinadas ao conhecimento científico 
ou simplesmente foram desconsideradas" no modelo formativo anterior (SILVESTRE; PLACCO, 2011, p. 35).

O que se considera, de maneira geral, é que esse segundo modelo de formação docente, como diz Morgado (2005), citado por Silvestre e Placco (2011), não hierarquiza a teoria e a prática, mas, ao contrário disso, estabelece uma relação dialética em que ambas se imbricam, completam e adaptam uma à outra. Trata-se de um modelo formativo que, antes de tudo, valoriza a prática docente, "pois é nela que o conhecimento profissional é construído e que vai se renovando, a partir do momento em que o professor se depara com novas situações da prática que lhe são desconhecidas e lhe causam dificuldades. São essas novas indagações que geram o processo reflexivo [...]" (SILVESTRE; PLACCO, 2011, p. 36).

Mesmo reconhecendo o valor do paradigma da racionalidade prática e admitindo que deve haver um processo reflexivo e investigativo sobre a prática, Silvestre e Placco (2011, p. 38) julgam que, nesse modelo de formação, esse processo encerra-se em si mesmo. Isso porque o professor reflete sobre sua prática, sendo capaz de modificá-la e aperfeiçoála para alcançar seus objetivos de ensino, mas sem ter a prática social como referência. O resultado disso, portanto, pode ser a repetição de modelos de ensino já vigentes, hegemônicos e de dominação. Assim, as autoras remetem ao paradigma da racionalidade crítica. Este viria a ser um modelo de formação emergente e contrahegemônico, que leva em conta o contexto sóciohistórico e político em que a educação se dá. Nessa concepção de formação, a educação é uma atividade social que deve ser desenvolvida por profissionais que a concebem no plano coletivo, transformando a escola em um espaço-tempo que pode vir a contribuir para um determinado projeto de sociedade. Assim, a formação inicial que está embasada nesse pressuposto oferece "a possibilidade de o professor perceber a dimensão política e cultural de seu ofício, oferecendo-lhe recursos para desenvolver sua profissionalização." (SILVESTRE; PLACCO, 2011, p. 39).

Ademais, podemos pensar nesse modelo de formação como uma oportunidade de desenvolver a profissionalidade do docente desde a sua formação inicial. Isso porque, no âmbito desse paradigma, o professor é um intelectual, ou seja, seu trabalho não é um mero exercício profissional técnico e instrumentalizado, tampouco essencialmente prático. Trata-se, pois, de uma atividade profissional intelectualizada, crítica, que tem a ciência como referencial teórico, mas que deve ser socialmente referenciada. $\mathrm{E}$, sendo o estágio "uma etapa de formação em que o futuro professor poderia compreender com mais profundidade a natureza socioprática do ofício docente" e que "precisaria estabelecer com mais eficiência uma interlocução entre os conhecimentos acadêmicos e os pedagógicos", como apontam Silvestre e Placco $(2011$, p. 4041), haveria nele uma abertura para o desenvolvimento da profissionalidade do docente desde sua formação inicial.

Assim, Silvestre e Placco (2011) dizem que o estagiário, em tese, não exerce ainda a profissão, mas, no momento em que ele desenvolve intervenções pedagógicas, durante os estágios curriculares, "são postos em jogo elementos que são constitutivos do seu processo de profissionalização" (SILVESTRE; PLACCO, 2011, p. 40). É preciso, pois, que o estagiário, nessa etapa da formação, "consiga pensar de uma forma mais elaborada o que o fez agir dessa ou daquela forma, ou quais conhecimentos, princípios, valores foram mobilizados para orientar sua prática pedagógica na escola" (SILVESTRE; PLACCO, 2011, p. 42). É por isso que a racionalidade crítica coloca-se, ao mesmo tempo, como referência e como desafio para a formação de professores socialmente comprometidos.

\section{A QUESTÃO DO ESTÁGIO CURRICULAR}

O estágio é um componente curricular que, nas diferentes áreas do conhecimento, exerce papel fundamental para a construção identitária do profissional. Isso porque, como asseveram Costa e Lima (2012, p. 140), "o processo de construção identitária do profissional com a sua profissão começa a se constituir, com mais ênfase, na formação inicial e tem a sua culminância nas atividades do Estágio". É nesse momento, como lembram as autoras, que a sociedade começa a reconhecer o estagiário/estudante como um profissional da área. "Assim, o estágio curricular é, por excelência, uma oportunidade de os alunos vivenciarem momentos que favoreçam um processo de identificação com o seu campo de atuação". (COSTA; LIMA, 2012, p. 140). 
Outro ponto importante que precisamos mencionar acerca dos estágios é a sua contribuição crítica e reflexiva para a formação do graduando, validando o paradigma crítico de formação. Tal fato se dá porque,

[...] além da questão
técnica do "saber fazer", o
Estágio se constitui como
um espaço de reflexão
sobre o curso, no sentido
de compreender a
realidade concreta de
vivência da profissão. Sua
obrigatoriedade leva em
consideração da
aplicabilidade
legislação, a consistência
teórica, a produção do
conhecimento, a relação
teoria e prática, a
docência e a pesquisa.
(COSTA; LIMA, 2012, p.
141).

É nessa perspectiva, lembram as autoras, que o estágio "não se reduz apenas à realização de uma função técnica, mas é uma atividade realizada por sujeitos pensantes, que podem promover mudanças no seu espaço de trabalho e na sociedade". Ademais, Costa e Lima (2012, p. 142) acrescentam que ele se torna um "espaço do desenvolvimento de uma práxis profissional, de constante investigação, análise crítica e questionamento, assumida como atitude de vida e profissão". Por isso, segundo as autoras, devemos concordar com a proposição de Lima (2008), que considera que a maior lição que os estágios trazem para formadores e formandos é a possibilidade de eles refletirem acerca do seu curso e da sua profissão.

Uma polêmica existente em torno do estágio é a dicotomia entre seus aspectos práticos e teóricos. Essa questão é amplamente discutida, uma vez que frequentemente o estágio é visto por formandos e formadores como uma etapa estritamente prática do curso, que não requer a teoria. Ou seja, como fruto de uma certa concepção e de uma forma de organização curricular dos próprios cursos de formação, criase uma cisão entre a academia e seus saberes teóricos, de um lado, e o campo de estágio e suas práticas de sala de aula, de outro lado. No entanto, é preciso entender que o estágio se constitui enquanto prática crítico-reflexiva. Para tanto, devemos acreditar que "a teoria ilumina a prática e a prática ressignifica a teoria", e, por isso, o estágio é um espaço por excelência para a atuação profissional fundada na relação teoriaprática no contexto do curso de graduação. (COSTA; LIMA, 2012, p. 141).

Pimenta e Lima (2006) também propõem a superação de algumas concepções tradicionais do estágio. Essas concepções, de modo geral, enxergam o estágio enquanto prática vazia de reflexão (a prática pela prática), ou mesmo uma prática que se resume à execução de técnicas previamente aprovadas que serviriam para serem imitadas/repetidas em qualquer situação ou contexto educacional, como se os alunos, a aprendizagem e as escolas fossem homogêneos. Assim, as autoras propõem uma concepção de estágio como uma atitude investigativa que, simultaneamente, irá envolver reflexão e intervenção na vida escolar, dos professores, alunos e da sociedade como um todo, afinal, a docência é uma prática social. Pimenta e Lima (2006, p. 6) afirmam, então, que o estágio "se constitui como um campo de conhecimento, o que significa atribuir-lhe um estatuto epistemológico que supera sua tradicional redução à atividade prática instrumental. [...] e, nesse sentido, o estágio poderá se constituir em atividade de pesquisa".

Indo mais além na definição do estágio, Pimenta e Lima assim se pronunciam:

[...] o estágio, nessa perspectiva, ao contrário do que se propugnava, não é atividade prática, mas atividade teórica, instrumentalizadora da práxis docente, entendida esta como a atividade de transformação da realidade. Nesse sentido, o estágio enquanto atividade curricular é atividade teórica de conhecimento,

fundamentação, diálogo e intervenção na realidade, esta sim objeto da práxis. Ou seja, é no trabalho docente no contexto da sala de aula, da escola, do sistema de ensino e da sociedade que a práxis se dá. (PIMENTA; LIMA, 2006, p. 14). 
Se aceitamos que o estágio é uma prática social, uma melhor compreensão desse momento formativo seria possível a partir do conhecimento e da análise das relações entre os sujeitos, as instituições de ensino, os conteúdos educativos e a prática pedagógica nele implicados. Isso porque

As atividades materiais
que articulam as ações
pedagógicas são as
interações entre os
professores, os alunos e os
conteúdos educativos em
geral para a formação do
humano; as interações
que estruturam os
processos de ensino e
aprendizagem;
interações nas quais se
atualizam os diversos
saberes pedagógicos do
professor, e nas quais
ocorrem os processos de
reorganização
ressignificação de tais
saberes [...]. (PIMENTA;
LIMA, 2006, p. 12).

Diante dos pontos aqui levantados, é possível identificar elementos positivos do estágio curricular para a formação inicial do licenciando, o qual, posteriormente, ampliará esses saberes em sala de aula e no contexto de atuação profissional. Alguns desses pontos positivos apontados por Costa e Lima (2012), e com os quais concordamos, são: (1) o estágio é um território plural, no qual os futuros professores se reconhecem como eternos aprendizes da profissão; nesse território, forjamse ideias, práticas, interações e formas de eles compreenderem a si mesmos no contexto da profissão; (2) o estágio é uma passagem; quando as perguntas e dificuldades básicas começam a ser superadas após algumas discussões, registros e relatórios, a carga horária prevista para o estágio chega ao seu fim, antes mesmo que se encontrem todas as respostas para as perguntas iniciais; já aí surgem outros desafios e perguntas e novas reflexões vão surgindo; (3) o estágio é lócus de formação do professor reflexivopesquisador, de aprendizagens significativas da profissão, de aproximação investigativa da realidade e do seu contexto social; é, portanto, um campo de conhecimento que envolve estudo, análise, problematização, reflexão e proposição de soluções sobre o ensinar e o aprender a profissão.
Por fim, destacamos que o estágio não só contribui para a formação do licenciando, mas também traz possibilidades de ampliação e reconfiguração das práticas escolares, na medida em que propicia interações diversas entre o docente em formação e os vários agentes da escola (entre eles, o professor supervisor), pondo em debate outras formas de enxergar as práticas de ensino.

\section{DELINEAMENTO METODOLÓGICO}

Como já dito, este trabalho, em termos gerais, visou investigar as contribuições que os estágios curriculares supervisionados podem trazer para a construção da identidade do professor de língua portuguesa. Já o nosso objetivo específico foi analisar os indícios de construção da identidade docente nos discursos dos professores em formação apresentados em seus relatórios de estágio. Para atingir os objetivos visados, escolhemos analisar os relatórios escritos de estágio que se constituíram, originalmente, em instrumentos de avaliação da aprendizagem dos licenciandos no âmbito do componente curricular correspondente. Tal fato pode ser justificado por acreditarmos que, nesse contexto formativo das escritas produzidas acerca das vivências do estágio, a construção da identidade profissional pode emergir. Afinal,

[...] ao ser possibilitada a
reflexão crítica do aluno-
mestre sobre essas
práticas de letramento,
realizadas entre os
domínios universitário e
acadêmico, durante os
estágios supervisionados,
o professor em formação
inicial pode se
conscientizar da relevância
do constante
aperfeiçoamento da
reflexão na/sobre a ação
docente ao longo da vida
profissional. (SILVA;
OLIVEIRA, 2018, p. 385).

Privilegiamos uma abordagem qualitativa em nossas análises, buscando fazer uma interpretação dos dados gerados na pesquisa. Como nossa proposta diz respeito à análise de materiais sem tratamento científico prévio, como é o caso dos relatórios de estágio, podemos dizer que trabalhamos com fontes primárias e, portanto, nossa pesquisa se constituiu como genuinamente documental. No caso deste 
estudo, o trabalho com fontes primárias de investigação se mostrou pertinente, dado o valor dos relatórios de estágio como narrativas reveladoras de muitas das dimensões do processo formativo de professores, entre elas a constituição da identidade docente.

Elegemos o curso de licenciatura em Letras-Português da Universidade Federal de Pernambuco (UFPE) como nosso campo de estudo por se tratar da nossa instituição/campo de formação e atuação. Além disso, definimos como corpus, especificamente, os relatórios apresentados pelos discentes do curso ao final do componente Estágio Curricular Supervisionado em Português 4 - que corresponde à regência de turma do ensino médio -, ofertado no semestre letivo 2019.1.

Trata-se de uma turma que tinha 25 alunos matriculados, todos do mesmo perfil curricular (matriz implantada em 2010), que haviam ingressado na instituição no mês de agosto de 2015. A turma contava também com uns poucos alunos de turmas/períodos anteriores que, por diversas razões, cursaram naquela ocasião o Estágio 4. Após excluirmos alguns alunos da contagem, devido a reprovações, e considerando que alguns deles desenvolveram o estágio em dupla, contamos com 18 amostras finais de relatórios escritos, realizadas por 20 estudantes.

Sobre as especificidades do Estágio 4, trata-se de uma disciplina com carga horária total de 90 horas, sendo 30 delas destinadas a encontros presenciais na universidade, $e$ as outras 60 horas são destinadas às atividades realizadas no próprio campo de estágio, subdivididas, por sua vez, em: atividades de observação e diagnose da turma escolhida para a regência (20h); planejamento e regência de sala de aula (20h) e atividades complementares (20h).

A avaliação da aprendizagem dos estagiários se dá mediante dois instrumentos principais. O primeiro é a produção de um projeto didático a ser desenvolvido na escola/campo de estágio após análise do grupoclasse a ser regido pelo estagiário; para a construção do projeto os graduandos recebem orientações tanto da professora orientadora do estágio, como de seus monitores. O segundo instrumento de avaliação é o relatório de estágio propriamente dito, por meio do qual são apreciadas as práticas desenvolvidas no estágio.

Para análise do material colhido na pesquisa, valemo-nos de alguns procedimentos, sempre tendo como pressuposto que as narrativas produzidas corresponderiam, em boa medida, às vivências e experiências dos estagiários nos campos de estágio.

Primeiramente, buscamos identificar através de uma leitura interpretativa - as "vozes" dos futuros professores, tentando compreender suas práticas. Finalizada essa leitura mais global dos relatos, propusemo-nos a observar especificamente, ainda que de forma também exploratória, e tendo por lastro as categorias trazidas em nosso referencial teórico, as menções dos estagiários à questão da identidade docente e/ou suas equivalentes. Desse modo, buscamos identificar trechos que tratassem explicitamente do ser professor, da carreira profissional, dos pontos positivos e negativos do exercício da docência, da (re)afirmação da escolha dos estagiários quanto ao ser professor de português. Para nos nortearmos inicialmente nessa análise, tomamos por base a nossa pergunta inicial de pesquisa: Os estágios curriculares são, de fato, um espaço-tempo de construção da identidade docente? A partir dessa primeira leitura exploratória, foram feitos esboços iniciais da análise, nos quais eram anotados os trechos recortados dos relatos dos estagiários e um comentário nosso, que orientava a interpretava o trecho lido. Finalizadas essas leituras iniciais, partimos para a análise de cada trecho, compreendo- o à luz de teorias expostas no referencial teórico.

É válido mencionar, ainda, que por se tratar de uma pesquisa prioritariamente qualitativa, não lançamos mão de categorias de análise previamente traçadas. Por isso, ao realizar a leitura exploratória aqui já mencionada, privilegiamos trechos dos relatos que poderiam exprimir impressões, considerações, sentimentos os mais variados, a partir das atividades desenvolvidas pelos formandos nos estágios e das suas interações com os grupos-classe regidos. Assim, atentamos para sentimentos como: frustração, animação, felicidade ou tristeza; identificamos, também, relatos acerca das reações dos alunos à presença do estagiário na escola e na sala de aula, por entendermos que comentários dessa natureza dizem respeito à forma como o licenciando se enxerga e é enxergado no cotidiano escolar. Além disso, levamos em conta na análise dos textos a presença de expressões como "identidade docente"; "formação docente"; "profissionalização"; "importância do estágio", 
dentre outras que se aproximavam mais diretamente dos tópicos temáticos que elencamos no aporte teórico para a discussão do tema da nossa pesquisa.

Nesse processo, enxergamos a possibilidade de dividir a análise em cinco tópicos ou categorias temáticas, como forma de melhor compreender os dados e torná-los produtivos para a discussão a ser feita. Desse modo, foram elencadas cinco categorias de análise: (i) as emoções retratadas pelos estagiários diante das aprendizagens construídas ao longo do estágio; (ii) o reconhecimento do estágio como etapa formativa para a construção do "ser professor"; (iii) a relação entre o estagiário, o professor supervisor e o processo formativo; (iv) práticas pedagógicas e escolares, realizadas pelos estagiários, que reafirmaram o processo formativo e identitário da docência; (v) algumas reflexões finais, sentimentos, desejos e frustrações dos estagiários frente aos ganhos e aos problemas do estágio.

\section{RESULTADOS E DISCUSSÃO}

Dentre os 20 estudantes cujos relatórios analisamos, 13 obtiveram notas acima da média estipulada pela UFPE (7,0 numa escala de 0,0 a $10,0)$; os demais obtiveram médias mais baixas, sendo que algumas delas foram recuperadas após a avaliação final - que consistiu na reescrita do relatório. Nesse caso, foi lida a primeira versão apresentada. A seguir, trazemos o resultado da análise por categoria. Salientamos antes que, a fim de manter o anonimato dos estagiários, cada um deles foi identificado por um número (E1, E2, E3... e assim por diante), que se repete na referência ao relatório de sua autoria (R1, R2, R3... e assim por diante). ${ }^{2}$

\section{AS EMOÇÕES RETRATADAS PELOS ESTAGIÁRIOS DIANTE DAS APRENDIZAGENS CONSTRUÍDAS AO LONGO DO ESTÁGIO}

Na escrita dos relatos reflexivos acerca do vivido nos estágios, os formandos lançam mão de sua memória afetiva para compartilhar suas vivências no campo de estágio. Assim, muitas vezes de modo emocionado, eles revelam suas inseguranças e apreensões, surpresas, dúvidas, entusiasmo e frustrações com relação a como o alunado vai responder às atividades pedagógicas propostas. Pudemos constatar que 14 dos 20

\footnotetext{
${ }^{2}$ As amostras serão referidas com os códigos RE1, RE2, RE3 e assim sucessivamente, e E1, E2, E3 e assim sucessivamente, sendo que R representa relato e E representa estagiário. Retirar vírgulas.
}

estagiários se colocaram de maneira emocionada frente aos resultados obtidos no campo de estágio. É interessante pontuarmos esses dados uma vez que, como afirmam Silva e Turbin (2011), a escrita sobre a prática profissional realizada pelo futuro professor nos relatórios de estágio se dá de maneira reflexiva e, por isso, "[...] permite ao aluno-mestre e aos professores um modo de aprender sobre a própria prática profissional; é um convite para visitar a sala de aula, ver o que está acontecendo e refletir sobre as ramificações de certos problemas ou sucessos." (SILVA; TURBIN, 2011, p. 109).

Ao refletir sobre suas práticas, os estagiários não só se identificam com o ofício de ensinar, como também podem lançar sobre ele um olhar crítico, visando a uma melhoria das atividades pedagógicas realizadas. Por esse motivo, fica evidente que essa é uma prática formativa para o graduando. Vejamos o que diz a estagiária 13:

\section{RE13}

"[...] infelizmente, nem todos os alunos participavam e colaboravam com a aula. [...] eu tentava introduzi-los no assunto [...] mas ouvia como respostas: 'ninguém prestou atenção nisso não, professora' ou 'assunto chato', e o grupo inteiro ria em tom de deboche. Respostas desse tipo provocavam mal-estar e aguçavam minhas reflexões sobre minha prática, a escolha de recursos didáticos e a maneira como eu estava conduzindo a aula. Será que existe uma fórmula perfeita? Não soube responder."

No trecho acima, é possível perceber a frustração sentida pela estagiária quando os alunos não reagiram bem ao conteúdo. Nesse momento, a formanda deixa evidenciada a reflexão que fez sobre sua prática, buscando fazer melhor futuramente. E essa busca, integrando uma formação reflexiva e crítica, faz parte da construção da identidade docente. Um outro exemplo desse processo de autoanálise dos estagiários é a seguinte afirmação da estagiária 4:

\section{RE4}

"[...] posso considerar que essa aula foi um pouco cansativa. Não sei se por causa de mim ou porque os alunos estavam mais dispersos, não sei de fato por qual motivo [...]. Senti-me desmotivada nessa aula, pois os alunos surgiram com perguntas que eu não sabia responder [...]. Pensando na minha prática em sala de aula, eu mudaria meu método dessa aula [...]." 
Nesse trecho, podemos perceber que o sentimento de frustração também está presente, o que nos leva a supor que há uma relação entre esse sentimento e o processo de construção da identidade do professor em formação, que se mostra capaz de identificar suas falhas, aceitar os limites do seu saber e buscar melhorar. Lembremos as palavras de Nakagome (2012, p. 207), que aponta a identidade como um processo de identificação do sujeito com pessoas ou coisas à sua volta, de modo que "uma pessoa não é um professor, mas gradualmente se torna um.". Ou seja, trata-se de um processo e, portanto, de uma construção. Nesse processo, muitas vezes o docente é convidado a revisitar sua prática e a modificá-la.

Adicionalmente ao que já citamos com relação à autorreflexão dos estagiários, há uma série de momentos em que estes deixam clara sua felicidade e empolgação com o êxito de suas práticas em sala de aula. Um exemplo disso são os seguintes relatos de dois estagiários:

RE10
"Fiquei bastante animada com o grupo-classe,
pois este reagiu positivamente à minha presença
e à aula ministrada."
RE18
"Fiquei muito feliz com o crescimento dos alunos.
[...] fez com que eu me sentisse com uma
sensação de dever cumprido. As aulas eram
sempre participativas, com questionamentos,
com comentários vindos por parte dos alunos."

Por outro lado, é interessante apontarmos também os momentos de frustração dos estagiários, sobretudo diante do baixo nível de engajamento dos alunos nas atividades:

\section{RE9}

"Diante desse panorama, eu fiquei muito frustrada e triste, visto que alguns alunos não produziram as resenhas em vídeo e não estavam interessados na aula."

Essas duas antagônicas sensações expressas pelos estagiários podem ser justificadas pelo fato de que o processo de ensino e aprendizagem não ocorre de maneira linear, ideia colocada por Dayrell (1996, p. 19) quando afirma: "[...] existe uma dinâmica e complexa rede de relações entre os alunos e destes com os professores, num processo contínuo de acordos, conflitos, construção de imagens e estereótipos, num conjunto de negociações [...]".

\section{O RECONHECIMENTO DO ESTÁGIO COMO ETAPA FORMATIVA PARA A CONSTRUÇÃO DO "SER PROFESSOR"}

Como já discutimos ao longo deste trabalho, "o Estágio curricular é, por excelência, uma oportunidade dos alunos vivenciarem momentos que favoreçam um processo de identificação com o seu campo de atuação" (COSTA; LIMA, 2012, p. 140). E é devido à sua capacidade de gerar a identificação do futuro docente com seu exercício profissional que ele se torna um relevante espaço-tempo formativo. Ratificamos essas considerações através do discurso dos próprios estagiários que, durante o período de regência de turma, vivenciaram situações que os levaram a compreender a necessidade dessa etapa curricular para a sua profissionalização. Consideremos o seguinte discurso como exemplo:

\section{RE25}

"O estágio agregou muito em minha carreira enquanto docente. As experiências vividas, a construção dos conhecimentos, as reflexões e as dúvidas sobre como proceder me fizeram uma professora mais completa e, com certeza, mais segura e preparada para enfrentar os desafios diários que encontrei enquanto docente."

Além disso, muitos licenciandos têm no estágio sua primeira oportunidade de iniciação ao magistério; por isso, certamente, o nervosismo da estreia em sala e os desafios iniciais da regência foram apontados pela estagiária 14:

\section{RE14}

"Estava bastante nervosa para o começo da regência, já que havia notado durante as observações que a turma era muito barulhenta por ser numerosa - e que, apesar de gostarem de conversar, não participavam das aulas."

Ademais, há estagiários que tomam esse início da regência como um marco para o reconhecimento social da sua identidade profissional enquanto docente. Vejamos o que diz a estagiária 22:

RE22
"Na primeira aula do estágio, foi o dia em que os
alunos tiveram contato comigo em uma


perspectiva diferente, isto é, enquanto professora, e que eu tive um contato diferente com eles, ou seja, eles tornaram-se meus alunos."

Os sujeitos de nossa pesquisa mostraram ter refletido, ao longo da experiência docente e da feitura do relatório, acerca do estágio curricular supervisionado, entendendo-o como um espaço de reafirmação de sua identidade profissional e de ampliação de seu processo formativo. Isso ocorreu, inclusive, com aqueles que já estavam familiarizados com a sala de aula por já terem realizado estágio não obrigatório em outras escolas. Sobre isso, vejamos mais alguns relatos.

\section{RE1}

"O período de estágio de regência foi um momento significativo, pois propiciou uma aproximação com a prática docente e a possibilidade de desenvolver estratégias didáticas visando um ensino-aprendizagem de língua em um caráter integrativo da linguagem."

\section{RE4}

"[...] a experiência que tive ao longo destes últimos meses foi maravilhosa, independente dos percalços. Os ganhos em relação à formação profissional foram imensos: aprendemos com os alunos, com a realidade escolar, com a professora supervisora. Fizemos o possível para driblar as dificuldades, sentimos raiva, receios, tristeza, chorei, chorei bastante. Choros de aflição, agonia, mas também de emoção [...] foi difícil, cansativo, mas necessário."

As reflexões empreendidas também contemplaram questões como a importância do planejamento para a prática docente e a consolidação da formação ao longo do tempo, principalmente durante os estágios e suas práticas:

RE1

"Diferentemente do estágio anterior, no estágio 4, pude me sentir, ao menos um pouco, como professora, [...]. Me senti mais segura para desenvolver o projeto, para propiciar as discussões. Foi uma constante preocupação com o processo de eficiência da relação ensinoaprendizagem, o que indicou uma consciência da importância do papel do professor enquanto mediador do conhecimento."

\section{RE5}

"A regência foi importante para me fazer refletir sobre o profissional que eu desejo ser e como eu quero atingir meus alunos nas minhas aulas. Estamos fadados ao discurso de como o alunado é ruim e desinteressado, mas não refletimos qual a nossa postura docente. Faltas, atrasos, aulas não planejadas tudo isso se reflete na forma como nossos alunos vão se comportar nas nossas aulas $[. . .]^{\prime \prime}$

As reflexões acima nos fazem lembrar as palavras de Castro e Salva (2012, p. 2): "Os estágios são momentos privilegiados de aprendizagem da docência, uma vez que permitem uma inserção mais efetiva do acadêmico no ambiente escolar, onde encontrará situações reais relacionadas ao processo de ensino-aprendizagem [...]". É nessa medida que o estágio enquanto componente curricular se torna tão importante, pois, uma vez que ele dá subsídios para o professor atuar de forma concreta no espaço de atuação profissional, requer uma articulação de saberes teóricos e práticos, tecendo o "todo" do currículo dos cursos de formação. A seguinte fala nos lembra isso:

RE9

"Ao debruçar-nos sobre as vivências do estágio, constatamos que um grande desafio com o qual o aluno de um curso de licenciatura tem de lidar é unir prática e teoria e, por isso, entendemos que não é só frequentando um curso de graduação que um indivíduo se torna um professor, mas é comprometendo-se como um produtor da práxis que o professor se forma. [...] é por meio do estágio de regência que se possibilita refletir criticamente sobre a práxis pedagógica $e$, sobretudo, repensar em soluções para os problemas que enfrentaremos futuramente."

Como lembram Costa e Lima, "é preciso que a prática nos ajude a compreender a profissão, a refletir sobre ela, a entendê-la no contexto das condições de trabalho dos seus profissionais, da realidade das instituições de ensino e nas relações com as relações de poder e oportunidades de inserção social" (COSTA; LIMA, 2012 , p. 140). Nesse sentido, o graduando vai ao campo de estágio e lá se depara com diversas situações do cotidiano escolar, e age sobre essas situações a partir do olhar crítico e reflexivo que a teoria lhe oferece. SUPERVISOR E O PROCESSO FORMATIVO 
Conforme já dito, dentre as características da identidade do profissional docente está o compromisso social e comunitário que o professor deve ter, auxiliando na formação de outros sujeitos além dos seus alunos. Em se tratando do estágio na licenciatura, essa função é claramente desempenhada pelos professores supervisores dos estágios. Pensando nisso, buscamos identificar nos relatórios analisados as contribuições que os professores supervisores do campo de estágio dão aos estagiários, uma vez que, sendo o estágio "uma etapa de formação em que o futuro professor poderia compreender com mais profundidade a natureza socioprática do ofício docente", ele exigiria, "daquele que está formando, clareza de como deve se dar a mediação desse processo" (SILVESTRE; PLACCO, 2011, p. 40-41).

Para aprofundarmos a compreensão acerca das contribuições dos formadores para a profissionalização do formando, devemos entender desde as situações em que a participação do professor supervisor de estágio é positiva para o êxito das atividades pedagógicas realizadas no campo de estágio, como também as participações negativas. Observemos, então, inicialmente algumas situações em que o estagiário julga que sua formação foi prejudicada pela postura adotada por seu supervisor de estágio:

\section{RE16}

"O professor supervisor não me avisou novamente [sobre o cancelamento da aula que a estagiária iria dar], o que me causou um grande desconforto. Em minha experiência na disciplina de Estágio Curricular Supervisionado em Português III, vivenciei uma outra realidade. Além da interação com a professora-supervisora, que foi excelente, houve da parte da professorasupervisora uma orientação constante, principalmente durante a regência. Então, ao iniciar a regência de Estágio IV, me deparei com um grande desafio: a pessoa que deveria ser para mim um modelo de professor e educador estava, na verdade, me mostrando tudo que eu não quero ser como educadora."

Outro exemplo de professor supervisor que interferiu no andamento do projeto didático das estagiárias é o seguinte, relatado pela estagiária 10:

\section{RE10}

"Sem avisar, o professor supervisor, que ainda não havia se sentado e permanecia próximo ao quadro, começou a falar o nome de alunos do 39 ano $B$ para que eles realizassem a leitura também. Foi um choque! Ele simplesmente tomou a frente da aula e continuou falando [...] Não havia problema nenhum em ler para a turma, o que me deixou desconfortável foi a atitude dele em tomar as rédeas da aula que eu deveria ministrar e me tratar como se eu estivesse ali apenas para uma participação secundária."

Outros casos de interferência da postura do professor supervisor no trabalho do estagiário foram a sua ausência em sala de aula e a diminuição da carga horária inicialmente disponível para a execução do planejamento, conforme se pode ver nos depoimentos das estagiárias 6 e 9:

\section{RE6}

"Encontrei algumas dificuldades no percurso da regência, por conta da ausência do professor em algumas aulas, o que fazia a turma ficar ainda mais dispersa, as conversas, $e$ as próprias dificuldades dos alunos em relação aos conteúdos."

\section{RE9}

"No que diz respeito à reescrita das produções, não foi possível solicitar a reescrita dos textos, pois o professor não disponibilizou a carga horária total estabelecida pela professora orientadora."

Algo que também ocorre durante os estágios, sendo muitas vezes o fator motivador da interferência dos supervisores no andamento do projeto didático do formando, é a desconfiança ou receio da qualidade da formação do estagiário, como se ele não fosse capaz de dar conta da sala de aula e dos conteúdos ministrados. Assim, o supervisor acaba por retirar a autonomia do professor em formação, como ilustrado no relato da estagiária 2:

\section{RE2}

"A professora supervisora passou a maior parte da minha regência - no final, ela parou - com a tabela de planejamento na mão, vendo meu próximo passo. Nessa aula, ela me chamou no canto e perguntou se eu não ia reexibir o curta."

Diante dos problemas apontados acima, podemos concordar com França (2013), que assevera:

Os professores que
recebem os alunos 
estagiários, muitas vezes, atuam no limite $d a$ concessão do espaço da sala de aula para que estes possam cumprir seu estágio, sem ter tido a oportunidade de compartilhar suas perspectivas de ensino e profissionais, num contexto em que as atividades desenvolvidas parecem compor um ritual que não foi estabelecido entre as partes. (FRANÇA, 2013, p. 77).

Em contraposição a essa postura, muitos professores que participam do processo de formação do estagiário se propõem a ser "aquele profissional experiente que assume a responsabilidade de conduzir o futuro professor nas inserções pelo ensino, em sua sala de aula na escola básica, garantindo que o estágio se configure como tempo de aprendizagem" (FRANÇA, 2013, p. 76). Sendo assim, os vínculos entre esses dois sujeitos (estagiário e supervisor) que participam do processo de formação se estreitam e favorecem um ensino de qualidade e articulado, tanto para os discentes da escola campo de estágio, quanto para os docentes em processo de formação. É o que se pode verificar nos seguintes trechos dos relatos das estagiárias 3, 5 e 17:

\section{RE3}

"Conhecer a realidade daqueles alunos um pouco mais de perto, ou seja, me aproximar um pouco de uma experiência positiva da escola pública no Brasil [...], fez-me ter inspiração, principalmente pela professora supervisora, que tanto me apoiou e deu mais condições para que o estágio fosse de sucesso, para a minha formação."

\section{RE5}

"Como nas aulas de segunda-feira existia uma janela no horário, esses momentos foram muitos importantes, pois a professora supervisora sempre me orientava e dava feedback de como estava meu desempenho e o que eu poderia melhorar."

\section{RE17}

"Dessa forma, percebi uma diferença enorme na postura dele enquanto supervisor e facilitador em relação ao que eu havia experienciado no estágio anterior - o que me fez refletir sobre a substancialidade de o professor supervisor confiar na autonomia do estagiário, oferecendo suporte para tal."

\section{Quando esse espaço para} compartilhamento e troca de saberes é aberto entre supervisor e estagiário, há uma grande contribuição para a construção de conhecimento e saberes da docência para ambos. Pudemos ver isso no seguinte trecho do relatório da estagiária 9 , no qual o supervisor reconheceu o quanto aprendeu com a estagiária durante sua vivência de estágio, revelando, inclusive que aquela prática de receber um estagiário em sala de aula era nova e, portanto, ele estava aprendendo e ensinando ao supervisionar o estágio:

\section{RE9}

"No que diz respeito à avaliação do professor supervisor sobre mim, ele afirmou que eu fui a primeira estagiária, visto que ele nunca foi procurado para ser professor supervisor. $O$ supervisor afirmou que tentou proporcionar uma experiência construtiva, pois ele afirmou que eu fui ele no passado e eu poderia ser ele no futuro. Também afirmou que aprendeu muito comigo não apenas na maneira que eu conduzia a aula, como também leu textos que, até então, nunca tinha lido e conheceu outro autor, tal como Mia Couto. [...] ademais, o professor supervisor afirmou que gostou do meu desempenho na regência e ficou feliz em poder participar do momento de formação de uma licencianda. Ele solicitou que os alunos aplaudissem. Diante desse panorama, eu fiquei muito feliz e emocionada pelo discurso e por ter possibilitado que ele repensasse as práticas de ensino."

Levando em conta todos esses ganhos formativos dos sujeitos do processo, acreditamos no estágio curricular como etapa basilar para a construção identitária do docente, uma vez que tanto formando quanto formador se reconhecem no exercício de ensinar e assumem a proposta de contribuir para a formação mútua e das futuras gerações.

\section{PRÁTICAS PEDAGÓGICAS E ESCOLARES, REALIZADAS PELOS ESTAGIÁRIOS, QUE REAFIRMARAM O PROCESSO FORMATIVO E IDENTITÁRIO DA DOCÊNCIA}


Objetiva-se com o estágio "a realização da prática de ensino estabelecendo a relação teoria e prática como efetivação do processo de ensino-aprendizagem" (CASTRO; SALVA, 2012, p. 2). A partir dessa concepção do estágio como etapa do processo formativo que abre diversas possibilidades de aprendizagem para o alunodocente, podemos encontrar, nas atividades desenvolvidas pelos licenciandos, indícios não só de uma identidade profissional emergente, como também de aprendizagens em torno de como exercer a profissão, por meio de uma prática reflexiva. Discutamos, então, esse processo a partir dos relatos dos estagiários que vivenciaram o exercício da profissão e tiveram oportunidade de refletir sobre questões de identidade profissional a partir de suas vivências.

\section{RE5}

"Desde do primeiro dia de regência, eu fazia a chamada que era online $e$, no celular da professora, ela abria o sistema SIEPE [Sistema de Informações Educacionais do Estado de Pernambuco] e colocava na página que tinha a relação do nome dos alunos [...] A elaboração da avaliação foi bem difícil para mim, pois foi a primeira vez que precisei fazer uma prova de múltipla escolha."

Nessa fala da estagiária 5, vemos que houve atividades pedagógicas que foram desempenhadas por ela, a partir de autorização e do auxílio da professora supervisora. Esse processo de mediação da supervisora - que dá autonomia para a estagiária entrar na dinâmica escolar e realizar as atividades da docente responsável pela turma regida - possibilita a aprendizagem da formanda sobre seu exercício profissional. Assim, ela pôde vivenciar a prática pedagógica, sempre de maneira teórico-reflexiva.

No próximo relato, há mais um exemplo de uma estagiária inserida com sucesso no campo de estágio, ao assumir as atividades da docência. Tal fato certamente enriqueceu sua formação, ratificando a importância do acolhimento do estagiário na escola, em parceria com seus diferentes agentes.

\section{RE1}

"Eu me sentia integrada ao corpo da escola, me relacionava bem com os professores, com 0 porteiro, com a gestora da escola, que sempre foi receptiva [...] O estágio funciona como um período de inserção na escola, nas atividades metodológicas, no exercício de gerir uma turma visando melhorias futuras a cada vez que formos adquirindo experiências em sala de aula, melhorando a postura, obtendo mais segurança e manejo com o assunto proposto para ser trabalhado."

Um outro aspecto a ser discutido no que tange à formação e à identidade docente é a questão da autoridade. Isso porque o espaço escolar é um espaço naturalmente heterogêneo, complexo e dinâmico, cujos agentes carregam diferentes marcas pessoais e culturais. O professor precisa, ao mesmo tempo, considerar essa diversidade e atuar como mediador, agir com clareza e garantir a organização do processo educativo, sem exercer violência sobre os alunos, uma vez que, "sempre que nos posicionamos perante um outro na qualidade de representantes hierárquicos de determinada prática social, seja com o intuito que for, estabelecemos uma relação, a rigor, violenta". (AQUINO, 1998, p. 8). Assim, é preciso assumir a autoridade docente, sem enveredar para o autoritarismo. Afinal, considerando as relações e interações que compõem a teia social, "[...] deve ficar claro que elas se prestam a diversos fins, tanto positivos como negativos: interações sociais podem ser fontes de informações verdadeiras ou preconceituosas, de independência ou de dominação, de alienação ou de tomada de consciência" (DAVIS, ESPÓSITO, SILVA, 1989, p. 52).

No trecho a seguir, a estagiária 1 sente dificuldade de lidar com a autoridade em sala de aula, processo que faz parte da formação docente.

\section{RE1}

"Tive bastante dificuldade em vários momentos para assumir uma postura de autoridade, me senti muito permissiva em sala [...]"

Em algumas situações, o formando já tem maior consciência da sua postura de autoridade em sala de aula e consegue refletir e agir em situações de conflito:

\section{RE11}

"O que aconteceu entre mim e esse aluno em questão? Chamei a atenção dele porque realmente foi necessário, para que ele se lembrasse de que a sala de aula é um lugar de promoção de respeito e alteridade, não o fiz para exercer autoritarismo em sala de aula. Após este acontecimento, tentei trazer o aluno de volta à realidade da sala, perguntando, e, quando ele emitia uma opinião, nunca o afastava, mas 
sempre buscava motivá-lo a participar das atividades."

Nota-se que a estagiária 11 traz para discussão suas dificuldades em sala de aula no que diz respeito à autoridade do professor, tornando evidente como essas situações pedagógicas têm relação com a construção identitária do profissional docente em suas práticas de ensino.

\section{ALGUMAS REFLEXÕES FINAIS, SENTIMENTOS, DESEJOS E FRUSTRAÇÕES DOS ESTAGIÁRIOS FRENTE AOS GANHOS E AOS PROBLEMAS DOS ESTÁGIOS}

Encerramos esta discussão com algumas questões pontuais sobre o estágio como um todo. Segundo os formandos, algumas problemáticas e alguns ganhos precisam ser discutidos nos cursos de formação de professores, a fim de contribuir para um melhor desenvolvimento dessa etapa formativa do curso. Silva e Turbin (2011) corroboram essa ideia ao afirmarem:

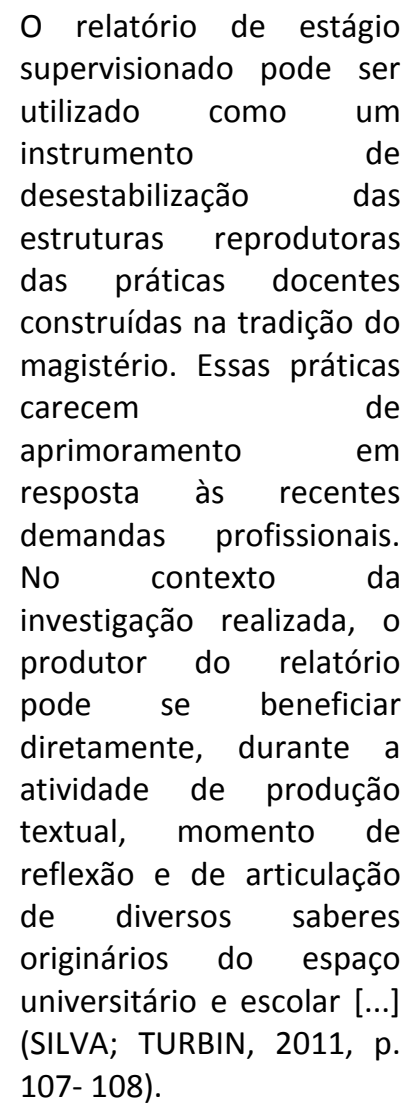

Com base nisso, vejamos algumas proposições de estagiários que apontam para a necessidade de mudanças no formato desse componente curricular, visando a contribuir para uma melhor formação, além de alguns problemas e conflitos vivenciados no campo de estágio e seu impacto na formação e na identidade profissional desses sujeitos:

RE6

"Algumas situações vividas em sala de aula são resumidas em falta de respeito: num dia em que o professor não foi para a escola, muitos alunos saíam da sala, ficavam no corredor conversando com alunos de outras turmas, não estavam com o menor interesse no que eu estava fazendo ali, $e$ também há muitas perguntas da vida pessoal que os alunos fazem, não respeitam a estagiária."

\section{RE20}

"Encerro, pois, esse processo com lacunas no que diz respeito às práticas dos professores observados e aos eixos de ensino de língua portuguesa que não foram bem desenvolvidos [...]. Também não saio com esperanças de alguma mudança no proceder da escola, pois, pelo analisado, as práticas estão consolidadas há anos e nenhum esforço para modificar essa realidade foi percebido."

\section{RE22}

"A princípio, senti-me desestabilizada, porque uma das maiores responsabilidades docentes diz respeito ao planejamento, o qual foi feito. Contudo, por razões da dinâmica do cotidiano escolar, o planejado, como havia sido articulado, não pôde ser realizado. Essa situação, por mais desagradável que tenha sido, ensinou-me a não ficar à mercê unicamente dos meios tecnológicos para que a aula pudesse acontecer."

Os relatos acima abordam as problemáticas vivenciadas pelos estagiários durante suas práticas: o currículo do cotidiano afetando o planejamento, professores supervisores ausentes, problemas de autoridade na turma, desrespeito dos discentes para com o estagiário etc. São momentos desafiadores vivenciados no contexto natural de ensino, que não é um ambiente monolítico e, por isso, pede respostas criativas e dinâmicas do professor, sempre visando à garantia da qualidade do trabalho pedagógico. Ademais, em alguns momentos, o próprio formato da disciplina de estágio, a organização das horas de trabalho e as exigências postas pelo planejamento didático e sua aplicação nos grupos-classe regidos são questões levantadas pelos licenciandos como empecilhos para uma formação mais plena: 
"No bojo das reflexões aqui desenvolvidas, vale ressaltar uma realidade negativa devido à forma como o estágio é configurado. Um fato é que o corpo discente não é previsível. Quer dizer, por ser a quantidade de horas dispostas à realização do estágio desproporcional à quantidade de metas de aprendizagem e conteúdos a serem alcançados com a turma, o processo de aprendizagem acaba sendo atropelado."

Apesar dos desafios do exercício profissional, emerge do processo de estágio um profissional que deseja realizar o trabalho docente, que se identifica com a profissão e enxerga a contribuição daquela experiência para sua formação:

\section{RE1}

"Essas adversidades serviram para me dar confiança e me fazer ver que é possivel realizar um trabalho que, ainda com imprecisões e certas falhas, tente ao máximo ser eficaz no sentido de promover reflexões acerca da língua a partir de estratégias didáticas que coloquem o aluno como protagonista, dando voz a ele."

É preciso atentarmos, no entanto, para o risco de construção dessa identidade do professor "missionário" que emerge em situações críticas de sala de aula. Esse modelo de identidade docente pode levar ao escamoteamento da profissão, que passa a ser encarada como uma "missão", um "dom", uma "vocação", e não como um exercício profissional como qualquer outro que, no corpo social, deve ser valorizado e remunerado (CORACINI, 2000). A estagiária 13 corrobora essa visão identitária da docência nos seguintes trechos:

\section{RE13}

"Com o passar do tempo percebi que a escola não é apenas um espaço de ensino-aprendizagem, mas de afeto.[...] além disso, percebi que a figura do professor [...] é também um construtor de 'pontes' que servem para ligar crianças, adolescentes, jovens e adultos a vários universos por meio do conhecimento.

É interessante pontuar, ainda, que a mesma estagiária 13, em outros momentos, enxerga a identidade docente, também, como a de um artista pronto para "entrar em cena, no palco" que é a sala de aula. Coracini (2000) também traz em seus estudos essa visão e identidade do professor como um "animador de plateias". Trata-se de uma visão identitária que emergiu na década de 1970 com a chegada dos recursos midiáticos e audiovisuais em sala de aula nas escolas, principalmente no ensino de língua. Vejamos como a estagiária se refere a si em sala de aula:

\section{RE13}

[...] Descobri que, da mesma maneira como um artista se sente realizado no palco das apresentações, eu me sinto realizada em uma sala de aula."

Em outros momentos dos relatos dos estagiários, aparece também a figura do professor engajado politicamente, um professor que encara o ensino como um ato político. Nesses trechos, geralmente, os estagiários, muitas vezes de maneira emocionada, falam do quanto gostariam de que os alunos com quem eles trabalharam no estágio pudessem ter um ensino de mais qualidade, falam de como sentirão falta dos discentes e de como é preciso valorizar a educação, que se encontra tão sucateada.

Segundo Candau (2014, p. 34), "Temos a profunda conviç̧ão de que estamos chamados/as a 'reinventar a escola', e nesse processo, o papel do professor é central. Tratase, na nossa perspectiva, de conceber o profissional da educação fundamentalmente como um agente sociocultural." Assim, como agente sociocultural, ele é imbuído de uma visão social e política que preza pela valorização e desenvolvimento da educação, não sendo, portanto, um profissional neutro. Vejamos exemplos desse engajamento docente como marca da identidade profissional de alguns estagiários e de sua preocupação com o ensino e os discentes:

\section{RE13}

"Encerro esta etapa com dois sentimentos contraditórios. De um lado, o sentimento de dever cumprido pelo feito de ter iniciado esta etapa tão importante para a minha formação [...]. Mas também saio com um enorme sentimento de pesar pela violência simbólica e silenciosa sofrida por aqueles alunos que ainda não se deram conta que estão à margem de uma sociedade excludente que tenta amordaçar nossas ideais e aniquilar nossos sonhos."

A estagiária se refere ao sucateamento da escola onde ela fez estágio, que está localizada numa zona rural, e às dificuldades do trabalho no 
turno noturno. Segue mais um trecho que corrobora essa visão política do fazer docente:

RE14-17
"Esse sentimento se tornou ainda melhor por
termos vivido essas experiências numa escola
pública, em tempos de descaso com a educação.
Sentimo-nos extremamente felizes por termos
contribuído significativamente para uma parte da
formação intelectual e humana de estudantes do
ensino básico. Como futuras docentes,
consideramos substancial que a preocupação do
professor transcenda os exercícios de
vestibulares, compreendendo a formação social,
política e intelectual de seu alunado."

Para finalizar a discussão dos dados, devemos citar os "ganhos" advindos do exercício profissional em sala de aula através dos estágios. Algumas falas, em tom emocionado, tratam o estágio como um momento decisivo para atestar a escolha pelo curso de graduação. Isso porque “pode-se dizer que 'ser-professor(a)' é uma construção angariada no decorrer de um longo processo, pois é preciso tempo para assimilar a formação, para aprender como agir, para tomar decisões e principalmente para se reconhecer como um formador das futuras gerações." (IZA et al., 2014, p. 276). Observemos alguns exemplos de relatos que demonstram a importância do estágio para a assimilação da escolha profissional dos formandos:

\section{RE11}

"Sendo este o último estágio da graduação, é inevitável não olhar para os quatro anos de curso $e$ entender que mesmo os conceitos mais abstratos estudados desde o primeiro período serviram para construir a profissional que eu sou e que eu estou me tornando: isso se mostrou nitidamente ao longo do estágio IV. [...] Certo que cada aluno de Letras ingressou na UFPE com um objetivo diferente [...] outro grupo, ao qual eu pertenço, já sabia que queria o curso de LetrasPortuguês. [...] outros se perderam, eu me perdi ao longo do curso. Mas me achei: nos estágios."

\section{RE13}

"O período da regência é sempre uma experiência desafiadora e provoca inúmeros questionamentos sobre a decisão que tomamos durante o vestibular sobre a carreira docente. [...] Sempre

\footnotetext{
${ }^{3}$ As estagiárias 14 e 17 fizeram o estágio em dupla e apresentaram, ao final, um relatório único, mas com relatos individuais da regência de sala propriamente dita. Por isso, ora há trechos em primeira pessoa do singular, ora há trechos em primeira pessoa do plural.
}

que imaginava ter que passar pelos estágios durante a minha formação, sentia um frio na barriga. O medo do desconhecido [...] muitas perguntas surgiram: será que estou fazendo a escolha certa mesmo?"

Depois de toda essa discussão, pode-se falar da natureza paradoxal do estágio curricular supervisionado, na medida em que, enquanto primeiro contato com o exercício docente, ele impacta a formação dos graduandos de diversas maneiras, tanto positiva como negativamente. Dado o caráter dinâmico e multifacetado do processo de ensino e aprendizagem, é costumeiro que o processo formativo do docente seja inquietante e prazeroso, ao mesmo tempo. Citamos aqui um trecho do relato da estagiária 5, que diz:

\section{RE5}

"Sumariamente, a regência foi incrível, criei laços afetivos com os alunos, gostaria de continuar sendo a professora deles, acredito que teríamos muito ainda para trabalharmos juntos. $O$ acolhimento da escola e da professora foi essencial para esse sentimento de conforto para desenvolver o projeto com a turma. Só tenho agradecimentos por esse momento na minha formação docente."

Concluímos nossa análise utilizando as palavras de Costa e Lima (2012): “o Estágio, em sua concepção mais ampla, propõe-se a instrumentalizar o estagiário para a reflexão sobre o seu fazer e sua identidade profissional." (COSTA; LIMA, 2012, p. 141).

\section{CONCLUSÃO}

Como colocamos desde o início, nosso maior objetivo foi contribuir para os estudos no campo da educação e formação de professores, entendendo mais profundamente $o$ funcionamento do processo multifacetado que é a construção identitária do profissional de Letras. Com esse intuito, voltamos nosso olhar para o estágio supervisionado, uma vez que, como postulam Costa e Lima (2012), é no território do estágio "que nascemos para a profissão e é nele que também renascemos constantemente, com novas ideias, novas práticas, novas interações e novas formas de compreender a nós mesmos no contexto da profissão na sociedade atual" (COSTA; LIMA, 2012, p. 149). Assim, partimos da hipótese que esse processo de identificação com a profissão docente se daria de maneira relevante durante os estágios curriculares 
supervisionados, já que estes se constituem num importante espaço-tempo de vivência da profissão; muitas vezes, até, o estágio corresponde ao primeiro contato do formando com o magistério numa dimensão prática.

Ao traçar nosso objetivo e nos lançarmos na análise dos nossos dados, pudemos confirmar nossa hipótese. Os estagiários não só destacaram em seus discursos a importância dos estágios como etapa formativa, como também foram além, problematizando questões identitárias do professor. Discutiram temas como a autoridade em sala de aula, o formato do currículo dos cursos de licenciatura e a relação teoria-prática. Nesse último caso, salientaram a necessidade de que ambas se articulem para a garantia de uma formação sólida e de um exercício profissional consciente. Ademais, discutiram as relações entre estagiários e supervisores, entre outras temáticas adicionais.

Essas questões corroboram a ideia de que a formação é um processo complexo, mas que, quando realizado de maneira crítica e reflexiva, amplia o alcance da atuação profissional, passando a englobar relações sociais mais amplas. Por outro lado, salvo em alguns poucos pontos, não reconhecemos no discurso dos licenciandos uma reflexão específica sobre a identidade do professor de português enquanto disciplina escolar. Assim, lançamos o desafio da continuidade da investigação do processo de formação docente e dos estágios curriculares enquanto uma etapa desse longo processo que é o "se reconhecer professor" e o "tornar-se professor de português", já que a docência é uma prática social que nos convida constantemente à (auto)reflexão.

\section{REFERÊNCIAS}

AGUIAR, Í. W. Contribuições dos estágios curriculares para a construção identitária do egresso do curso de licenciatura em letras língua portuguesa da universidade federal de Pernambuco. 2016. 86 f. Monografia (Graduação em Letras) - Universidade Federal de Pernambuco, Recife, 2016.

AQUINO, J. G. A indisciplina e a escola atual. Rev. Fac. Educ., São Paulo, v. 24 n. 2, p. 1-11, jul./dez. $1998 . \quad$ Disponível em: https://www.scielo.br/scielo.php?script=sci artte xt\&pid=S010225551998000200011\&lng=pt\&tlng=pt. Acesso em: 11 dez. 2020. DOI:10.1590/S0102$\underline{25551998000200011}$

CANDAU, V. M. F. Ser professor/a hoje: novos confrontos entre saberes, culturas e práticas. Educação, Porto Alegre, v. 37 , n. 1, p. 33- 41, jan./abr. 2014. Disponível em: Acesso em: https://revistaseletronicas.pucrs.br/ojs/index.ph $\mathrm{p} /$ faced/article/view/15003. $11 \mathrm{dez}$. 2020.DOI:10.15448/1981-2582.2014.1.15003

CASTRO, A. T. K. A.; SALVA, S. Estágio como espaço de aprendizagem profissional da docência no curso de pedagogia. In: ANPED SULSEMINÁRIO DE PESQUISA EM EDUCAÇÃO DA REGIÃO Sul, 9., 2012, Santa Maria. Anais... Santa Maria: UFSM, 2012. Disponível em: http://www.ucs.br/etc/conferencias/index.php/a npedsul/9anpedsul/paper/viewFile/532/437.

Acesso em: 27 de nov. 2019.

CONTRERAS, J. Autonomia de professores. São Paulo: Cortez, 2002.

CORACINI, M. J. R. F. Subjetividade e identidade do professor de português (LM). Trab. Ling. Apl., Campinas, v. 36, p. 147- 158, jul./dez. 2000.

COSTA, E. A. S.; LIMA, M. S. L. Os desafios da aprendizagem da profissão e o estágio. Revista Expressão Católica, Quixadá, CE, v. 1, n. 2, p. 13951, 2012. Disponível em: http://publicacoesacademicas.unicatolicaquixada .edu.br/index.php/rec/article/view/1302. Acesso em: 11 dez. 2020. DOI:10.25190/rec.v1i2.1302

DAVIS, C.; SILVA, M. A. S. E.; ESPÓSITO, Y. Papel e valor das interações sociais em sala de aula. Cadernos de Pesquisa, São Paulo, n. 71, p. 49-54, nov. 1989.

DAYRELL, J. T. A. escola como espaço sociocultural. In: DAYRELL, J. T. A. (org.). Múltiplos olhares sobre educação e cultura. Belo Horizonte: UFMG, 1996, p. 136-161.

FRANÇA, D. S. A supervisão dos estágios de ensino pelos professores da educação básica: limitações e desafios. Olh@res, Guarulhos, v. 1, n. 1, p. 64- 89, maio. 2013. Disponível em: https://periodicos.unifesp.br/index.php/olhares/ article/view/47. Acesso em: 11 dez. 2020. DOI:10.34024/olhares.2013.v1.47 
GRECO, E. A. A imagem do professor construída pela revista Veja. In: JORNADA INTERNACIONAL DE ESTUDOS DO DISCURSO E ENCONTRO INTERNACIONAL DA IMAGEM EM DISCURSO, 1., 2012, Maringá. Anais.... Maringá: Universidade Estadual de Maringá, 2012.

IZA et al. Identidade docente: As várias faces da constituição do ser professor. Revista Eletrônica de Educação, São Carlos, v. 8, n. 2, p. 273-292, 2014. Disponível em: http://www.reveduc.ufscar.br/index.php/revedu c/article/viewFile/978/339. Acesso em: $11 \mathrm{dez}$. 2020.DOI:10.14244/198271999978

LIMA, M. S. L. Reflexões sobre o estágio/prática de ensino na formação de professores. Rev. Diálogo Educ., Curitiba, v. 8, n. 23, p. 195-205, jan./abr. 2008. Disponível em: https://periodicos.pucpr.br/index.php/dialogoed ucacional/article/view/4015. Acesso em: $11 \mathrm{dez}$. 2020. DOI:10.7213/rde.v8i23.4015

NAKAGOME, P. T. Identidade docente em formação. Linha d'Água, São Paulo, v. 25, n. 1, p. 203-217, 2012. Disponível em: https://www.revistas.usp.br/linhadagua/citations tylelanguage/get/modern-languageassociation?submissionld=37373\&publicationld= 30038. Acesso em: 11 dez. 2020.

DOI:10.11606/issn.2236-4242.v25i1p203-217

PERES, A. F.; GRECO, E. A. O sujeito professor de língua portuguesa: a construção de uma imagem. Entretextos, Londrina, v. 14, n. 1, p. 190-205, jan./jun. 2014.

PIMENTA, S. G.; LIMA, M. S. L. Estágio e docência: diferentes concepções. Revista Poiésis Pedagógica, Catalão, v. 03, n. 3 e 4, p. 5-24, 2006.
MORGADO, José Carlos. Currículo e profissionalidade docente. Portugal: Porto Editora, 2005.

PEREIRA, D. C.; OVIGLI, D. F. B. Estágio supervisionado: relatos do processo de constituição da identidade docente em UberabaMG. Revista Profissão Docente, Uberaba, v. 17, n. 37, p. 51-62, ago./dez. 2017. Disponível em: http://www.revistas.uniube.br/index.php/rpd/art icle/view/1136. Acesso em: 11 dez. 2020.

DOI:10.31496/rpd.v17i37.1136

QUADROS, V. C.; KOCHHANN, M. E. R. O estágio curricular supervisionado no curso de licenciatura em matemática: relações entre saberes e identidade docente. Revista Prática Docente, Confresa-MT, v. 3, n. 1, p. 5-18, jan./jun. 2018. Disponível em: http://periodicos.cfs.ifmt.edu.br/periodicos/inde x.php/rpd/article/view/74. Acesso em: $11 \mathrm{dez}$. $2020 . \quad$ DOI:10.23926/RPD.25262149.2018.v3.n1.p5-18.id74

SILVA, W. R.; OLIVEIRA, E. J. Estágio curricular da licenciatura como um contexto de pesquisa sobre formação inicial do professor. Soletras, Rio de Janeiro, n. 35, p. 379- 404, jan./ jun. 2018. Disponível em: https://www.epublicacoes.ueri.br/index.php/soletras/article/vie w/31641. Acesso em: 11 dez. 2020. DOI:10.12957/soletras.2018.31641

SILVA, W. R.; TURBIN, A. E. F. Relatório de estágio supervisionado como registro da reflexão pela escrita na profissionalização do professor. Polifonia, Cuiabá, MT, v. 18, n. 23, p. 103-128, jan./jun., 2011.

SILVESTRE, M. A. PLACCO.; V. M. N. DE S. Modelos de formação e estágios curriculares. Formação Docente, Belo Horizonte, v. 03, n. 05, p. 30-45, ago./dez. 2011. 